\title{
Peningkatan Penguasaan Konsep Biologi Siswa Menggunakan Strategi Kooperatif Stad
}

\author{
Jahidin 1 \\ 1Pendidikan Biologi-Universitas Negeri Malang
}

INFO ARTIKEL

\section{Riwayat Artikel:}

Diterima: Tgl-Bln-Thn

Disetujui: Tgl-Bln-Thn

\section{Kata kunci:}

Kata kunci 1

Kata kunci 2

Kata kunci 3

Kata kunci 4

Dst...

\author{
Alamat Korespondensi: \\ Jahidin \\ Pendidikan Biologi \\ Universitas Negeri Malang \\ Jalan Semarang 5, Malang 65154 \\ E-mail: j.jahidin@yahoo.co.id
}

Penguasan konsep atau materi pelajaran biologi tidak terlepas dari sebuah efek strategi pembelajaran yang diterapkan oleh guru. Pentingnya pengimplementasian strategi belajar telah ditegaskan oleh (Goethals, Howard, \& Sanders, 2004; Good \& Brophy, 2000), bahwa menerapkan strategi dan cara siswa belajar untuk menggunakan strategi merupakan suatu cara untuk memastikan bahwa isi dan keterampilan yang diajarkan lebih dapat diakses oleh semua siswa. (Widodo, 2017) strategi belajar lebih diutamakan dibandingkan dengan seberapa banyak siswa memperoleh dan mengingat pengetahuan. Penerapan strategi belajar dapat mendorong siswa menjadi self-regulater learning (Butler, 1994; Butler \& Winne, 1995; Paris \& Byrnes, 1989). Gagne (dalam Degeng, 1989), belajar telah terjadi apabila siswa telah memperoleh kapabilitas tertentu untuk melakukan sesuatu.

Student Team Achievement Division (STAD) merupakan strategi kooperatif yang paling sederhana dan cocok digunakan guru yang baru mulai menggunakan strategi kooperatif (Slavin, 2005), mampu menghadirkan suasana belajar yang efektif (Slavin, 2006), serta menekankan kerjasama dan tanggung jawab kelompok untuk mencapai ketuntasan belajar dengan melibatkan peran siswa sebagai tutor sebaya (Arends, 2008). Telah dilaporkan bahwa STAD menghadirkan suasana belajar yang efektif dalam pembelajaran IPA (Slavin, 2006), serta berpengaruh terhadap pencapaian kompetensi biologi pada rana kognitif, afektif, dan psikomotor (Soedjono, 2007). (Norman, 2005) mengemukakan pembelajaran STAD di kelas 3-12 secara signifikan dapat meningkatkan kemampuan akademik siswa dibandingkan dengan metode tradisional. (Slavin, 2006) mengemukakan bahwa $69 \%$ kajian STAD menunjukkan pengaruh positif yang signifikan. 
Pelaksanaan pembelajaran kooperatif dalam ruangan kelas sering tergantung pada kemampuan guru untuk menggunakannya. Memodelkan, mendemonstrasikan, dan mempraktikan pendekatan-pendekatan pembelajaran seperti berbagi, mendengarkan, mengintegrasikan gagasan-gagasan lain, dan penanganan perselisihan paham adalah merupakan hal-hal yang terpenting. Pembelajaran kooperatif menyertakan siswa dalam memahami isi materi pembelajaran (Goethals et al., 2004; Good \& Brophy, 2000). (Branch \& Oberg, 2004) bahwa pengetahuan baru siswa dapat digunakan untuk menjawab pertanyaan, mengembangkan suatu solusi atau untuk mendukung suatu pola berpikir. Banyaknya aktivitas belajar akan menghasilkan pengalaman belajar semakin banyak. Dengan demikian, semakin berkualitas dan banyak pengalaman belajar, semakin berkualitas dan makin banyak pula hasil yang diperoleh (Arends, 2012).

Hasil belajar yang ditampilkan oleh siswa adalah sebagai wujud terjadinya penguasan konsep dari materi yang dipelajar, baik berupa konsep kongrit maupun konsep abstrak. (Degeng, 1989), siswa telah belajar konsep kongkrit apabila ia telah dapat mengidentifikasi contoh-contoh baru dari sekelompok objek yang dapat diidentifikasi dengan definisi. Sedangkan pada konsep abstrak, siswa dikatakan telah belajar konsep abstrak apabila ia menggunakan suatu definisi untuk mengklasifikasikan contoh-contoh yang tidak dipelajari sebelumnya.

Berdasarkan kekhasan strategi koperatif STAD tersebut, implementasi dalam pembelajaran biologi dapat meningkatkan penguasaan konsep. (Arni, Jahidin, \& Suriana, 2019) mengemukakan bahwa siswa yang bekerja sama memecahkan atau menyelidiki beberapa masalah, maka siswa terlibat dalam pengembangan bakat-bakat lainnya seperti merencanakan, mengorganisasikan, komunikasi sosial, kreativitas dan kemampuan akademik. Jika siswa terlibat aktif dalam pembelajaran, siswa akan terhindar dari pola-pola belajar tradisional yaitu menghafal dan menjadikan siswa untuk mengasimilasi dan mengakomodasi informasi. (Arends, 2008) melaporkan bahwa dari 45 studi yang direview, 37 diantaranya menunjukkan bahwa kelas-kelas dengan pembelajaran kooperatif memiliki prestasi belajar yang lebih baik secara signifikan dibandingkan dengan kelas-kelas kontrol. (Lie, 2002) menjelaskan bahwa dalam pembelajaran kooperatif secara khusus siswa berperan sebagai sumber belajar antara satu dengan lainnya, berbagi informasi dan mengumpul informasi, serta saling membantu untuk mencapai keberhasilan bersama. Dengan demikian, strategi kooperatif STAD memberikan peluang bagi siswa untuk berkreasi, berkembang, dan menunjukkan kemampuan pada tingkat individu maupun kelompok.

\section{METODE}

\section{Tempat dan Waktu Penelitian}

Penelitian dilaksanakan di 6 sekolah SMA Negeri Kota Bau-bau pada kelas X Tahun Pelajaran 2008/2009. Penelitian berlangsung selama 1 semester mulai bulan Januari sampai dengan Juni 2009.

\section{Populasi dan Sampel Penelitian}

Populasi penelitian adalah siswa kelas X SM A N egeri Kota Bau-bau Provinsi Sulawesi T enggara yang terdaftar pada semester genap tahun pelajaran 2008/ 2009.

Sampel penelitian adalah siswa kelas $\mathrm{X}$ yang berjumlah 432 siswa. Sampel diambil secara acak dengan menentukan 2 kelas di setiap SMA negeri sehingga diperoleh 12 kelas, yaitu 6 kelas diajar menggunakan strategi kooperatif STAD dan 6 kelas diajar menggunakan strategi konvensional.

\section{Instrumen Penelitian}

Instrumen yang digunakan sebagai pengumpul data penelitian adalah tes pilihan ganda berjumlah 28 soal dan tes uraian berjumlah 10 soal. Tes pilihan ganda memiliki reliabilitas 0,90 (uji reliabilitas menggunakan KR-20) dan tes uraian memiliki reliabilitas 0,84 (uji reliabilitas menggunakan alpha Cronbach).

\section{Pengumpulan Data}

Data penelitian dikumpulkan melalui pemberian pretest dan posttest. Pemberian pretest dilakukan sebelum pelaksanaan penelitian eksperimen sedangkan pemberian posttest dilakukan setelah pelaksanaan penelitian eksperimen (penerapan pembelajaran menggunakan strategi kooperatif STAD dan strategi konvensional). Waktu pelaksanaan pretest dan posttest berdurasi 90 menit. 


\section{Analisis Data}

Data hasil penelitian dianalisis menggunakan uji analisis kovariansi (anacova) dengan bantuan program SPSS-PC 16.0 For Windows. Pengujian hipotesis dilakukan pada taraf signifikansi 0,05. Jika terdapat pengaruh yang signifikan, dilakukan uji lanjut menggunakan Least Significance Difference (LSD) pada taraf signifikansi 0,05 .

\section{HASIL PENELITIAN}

Tabel 1 menunjukkan nilai $\mathrm{F}=37,77$ dengan nilai signifikansi 0,00 . Nilai signifikansi ini lebih kecil dari alpha 0,05 , sehingga hipotesis penelitian $\left(\mathrm{H}_{1}\right)$ diterima dan menolak hipotesis statistik $\left(\mathrm{H}_{0}\right)$. Dengan demikian dapat disimpulkan ada pengaruh strategi pembelajaran terhadap penguasaan konsep biologi siswa.

Tabel 1. Ringkasan Hasil Uji Anacova.

\begin{tabular}{cccccc}
\hline Soure & Sum of Square & df & Rata-rata Square & F & Sig. \\
\hline Corrected model & $10061,615^{\mathrm{a}}$ & 6 & 1676,936 & 37,366 &, 000 \\
Intercept & 6413,266 & 1 & 6413,266 & 142,904 &, 000 \\
Penguasaan konsep & 2580,483 & 1 & 2580,483 & 57,500 &, 000 \\
Strategi & 3390,309 & 2 & 1695,155 & 37,772 &, 000 \\
Error & 19073,197 & 425 & 44,878 & & \\
Total & 277535,000 & 432 & & & \\
Corrected total & 29134,812 & 431 & & & \\
\hline
\end{tabular}

Hasil uji lanjut (Tabel 2) diperoleh skor rata-rata terkoreksi penguasaan konsep biologi menggunakan strategi kooperatif STAD adalah 39,34 dan strategi konvensional adalah 29,58. Dengan demikian, rata-rata skor penguasaan konsep biologi siswa menggunakan strategi STAD lebih tinggi 9,76\% dibandingkan strategi konvensional.

Tabel 2. Ringkasan Hasil Uji LSD.

\begin{tabular}{cccccc}
\hline $\begin{array}{c}\text { Strategi } \\
\text { Pembelajaran }\end{array}$ & $\begin{array}{c}\text { Rata-rata } \\
\text { Pretest }\end{array}$ & $\begin{array}{c}\text { Rata-rata } \\
\text { Posttest }\end{array}$ & Selisih & $\begin{array}{c}\text { Rata-rata } \\
\text { Terkoreksi }\end{array}$ & $\begin{array}{c}\text { Notasi } \\
\text { LSD }\end{array}$ \\
\hline Konvensional & 19,02 & 29,03 & 10,02 & 29,58 & $\mathrm{a}$ \\
STAD & 20,28 & 39,66 & 19,37 & 39,34 & $\mathrm{~b}$ \\
\hline
\end{tabular}

\section{PEMBAHASAN}

Penggunaan strategi pembelajaran yang tepat terhadap suatu konsep atau materi pembelajaran diharapkan dapat meningkatkan penguasaan konsep siswa. Berdasarkan hasil analisis anacova menunjukkan strategi pembelajaran berpengaruh signifikan terhadap penguasaan konsep biologi $(\mathrm{F}=37,772, \mathrm{p}<0,05)$. Adanya pengaruh signifikansi dapat diartikan bahwa perbedaan penguasaan konsep biologi siswa sebagai akibat penerapan strategi pembelajaran. (Arends, 2008) bahwa model atau strategi pembelajaran dapat membantu siswa mendapatkan informasi baru, mempelajari berbagai keterampilan penting dan memikirkan serta memproses informasi yang sudah diperoleh.

Perbedaan hasil penguasaan konsep tersebut tergambar dari adanya perbedaan rata-rata skor penguasaan konsep biologi siswa yang diajar dengan strategi kooperatif STAD lebih tinggi dari strategi konvensional. Hasil penelitian ini sejalan dengan penegasan (Arends, 2008) bahwa dari 45 studi yang direview, 37 studi menunjukkan bahwa prestasi belajar kelas pembelajaran kooperatif lebih baik secara signifikan dibandingkan kelas kontrol, sedangkan delapan studi lainnya tidak menemukan adanya perbedaan yang signifikan dengan kelas kontrol. Dalam tinjauan lain, terjadinya peningkatan pemahaman konsep biologi siswa melalui pembelajaran kooperatif juga sejalan dengan pendapat (Toseland, Jones, \& Gellis, 2004) bahwa penggunaan strategi kooperatif juga tidak terlepas dari keefektifan kelompok sehingga mereka sanggup untuk: (1) memahami proses-proses perubahan kelompok sepanjang terjadinya interaksi antar anggota kelompok; (2) mempertimbangkan pengaruh perubahan anggota kelompok dari perbedaan ras, dan sosial ekonomi; (3) menilai pengaruh perubahan cepat dalam kelompok untuk berfungsinya kelompok; (4) memandu perkembangan perubahan kelompok untuk memfasilitasi partisipasi anggota kelompok dan kepuasan selama melaksanakan simulasi yang memungkinkan kelompok untuk mencapai tujuan. 
Adanya peningkatan penguasaan konsep biologi pada strategi kooperatif STAD juga didukung oleh teori zona of proximal development dari Vigotsky, yaitu zona yang berada diantara tingkat perkembangan aktual dan tingkat perkembangan potensial. Tingkat perkembangan aktual menentukan fungsi intelektual individu saat ini dan kemampuannya untuk mempelajari sendiri hal-hal tertentu. Tingkat perkembangan potensial yaitu tingkat yang dapat difungsikan atau dicapai oleh individu dengan bantuan orang lain. Nilai penting dari ide Vigotsky ini adalah bahwa belajar terjadi melalui interaksi sosial dengan guru dan teman sebaya. Dengan tantangan dan bantuan yang tepat dari guru dan sebayanya yang lebih mampu, siswa maju ke zona of proximal development tempat pembelajaran baru terjadi. Hasil penelitian ini juga bersandar pada perspektif kognitif-konstruktivis dari (Piaget, 1975) bahwa pelajar dengan umur berapa pun terlibat secara aktif dalam proses mendapatkan informasi dan mengkonstruksi pengetahuannya sendiri. Pengetahuan tidak statis, tetapi berevolusi dan berubah secara konstan selama pelajar mengkonstruksikan pengalamanpengalaman baru yang memaksa mereka untuk mendasarkan diri pada pengetahuan dan memodifikasi pengetahuan sebelumnya. Dijelaskan oleh (Arends, 2008; Vygotsky, 1994) bahwa dalam usaha menemukan pemahaman, individu menghubungkan pengetahuan baru dengan pengetahuan sebelumnya dan mengkonstruksikan makna baru.

Hasil penelitian ini telah menunjukkan bahwa strategi STAD sebagai sebuah strategi pembelajaran yang lebih efektif untuk meningkatkan penguasaan konsep biologi siswa dibandingkan strategi konvensional. Hasil penelitian lain yang mendukung adalah oleh (Newmann \& Thompson, 1987) yang telah mereview 27 laporan hasil penelitian di tingkat SMP dengan melibatkan model pembelajaran kooperatif STAD, TGT, Jigsaw, learning together, dan GI dan hasilnya STAD menunjukkan peningkatan pemahaman siswa yang lebih baik. Peningkatan penguasaan konsep biologi yang lebih baik pada siswa yang belajar menggunakan strategi STAD mengindikasikan strategi STAD lebih efektif memfasilitasi siswa mengelaborasi konsep yang lebih baik. Bruner, (1980) dalam (Degeng, 1989) mengemukakan bahwa suatu konsep memiliki unsur nama, contoh, karakteristik, dan definisi. Seseorang dikatakan memahami suatu konsep apabila ia mengetahui semua unsur dari konsep itu.

Siswa yang mampu meningkatkan penguasaan konsep merupakan konsekuensi kesadaran diri akan belajar. Peningkatan penguasaan konsep biologi dalam penelitian ini adalah peningkatan skor rata-rata dari pretes ke posttes. Hasil penelitian ini sejalan dengan penelitian (Johnson \& Johnson, 2017) yang telah membandingkan keefektifan beberapa strategi kooperatif berdasarkan lima dimensi penilaian, yaitu: (1) kemudahan metode mengajar; (2) kemudahan penggunaan awal dalam kelas; (3) kemudahan metode dalam memanfaatkan waktu; (4) ketahanan metode (aplikasinya pada berbagai variasi tempat dan tingkat kelas); dan (5) kemudahan adaptasi metode terhadap perubahan kondisi.

Perbedaan penguasaan konsep siswa antara strategi STAD dan konvensional juga sejalan dengan Language Australia (2000); ERIC (2002) yang melaporkan bahwa perbedaan kesuksesan siswa karena kurangnya pemahaman terhadap strategi dan perilaku yang memungkinkan mereka memperoleh informasi dan keterampilan baru. Informasi tersebut tersintesis dengan baik sebagai suatu perolehan dalam proses belajar anak usia dewasa. Lebih lanjut (Slavin, 1995) mengemukakan bahwa elaborasi kognitif akan terjadi dalam diri siswa jika informasi dapat tersimpan dalam memori serta menghubungkannya dengan informasi yang tersimpan sebelumnya, sehingga siswa dapat merestrukturisasi atau mengembangkan materi yang dipelajari. Cara yang paling efektif untuk mengetahui pencapaian ini adalah mampu menjelaskannya kepada orang lain.

Penguasaan konsep biologi pada strategi pembelajaran kooperatif STAD merupakan akibat dari kekompakan dan kerjasama anggota kelompok dalam menyelesaikan tugas. Strategi ini menekankan pada kemandirian anggota tim dalam mengemukakan pendapat (brainstorming) selama aktivitas diskusi kelompok. Dalam meningkatkan proses brainstorming, (Osborn, 1963) mengusulkan penataan khusus untuk memfasilitasi kreativitas dalam branstorming, meliputi: (1) ekspresi, yaitu memberikan harapan pada anggota tim untuk mengungkapkan ide apa saja untuk dipikirkan; dan (2) kualitas, yaitu menceritakan pada kelompok untuk menghasilkan banyak ide dan mengembangkan ide atas ide-ide lainnya. Proses kerja tim dapat membantu kelompok untuk menyeleksi lebih kreatif ide dan menggunakan ide yang diperoleh tim untuk meningkatkan diskusi dan debat kelompok (Schulz-Hardt, Jochims, \& Frey, 2002).

Keefektifan pembelajaran kooperatif STAD dalam meningkatkan pemahaman konsep biologi siswa juga didukung oleh Vockell, (no date) bahwa ada delapan langkah yang harus dilalui selama belajar, yaitu: (1) attention yaitu siswa memfokuskan perhatian dalam aktivitas belajar; (2) expectancy yaitu siswa mengembangkan harapan untuk menemukan suatu hasil dari proses belajar yang dijalankan (perolehan 
motivasi); (3) retrieval of relevant information to working memory yaitu siswa membangkitkan kembali dari struktur long-term memory untuk membantu mempelajari informasi baru atau menemukan cara memecahkan masalah; (4) selective perception yaitu siswa memfokuskan perhatian pada presentasi pembelajaran yang esensial; (5) encoding yaitu memasukan informasi ke dalam long-term memory; (6) responding yaitu siswa mengingat kembali dan secara aktif menggunakan informasi yang telah tersimpan dalam long-term memory; (7) feedback yaitu siswa mendeterminasi tingkat tampilan selama fase sebelumnya sehingga dapat memberikan kepuasan bagi siswa; dan (8) cueing retrieval yaitu siswa mengingat kembali atau menerapkan informasi yang telah dipelajari sebelumnya pada tingkatan retensi informasi atau transfer belajar diluar konteks aslinya ke suatu aplikasi baru.

Dengan demikian, peningkatan penguasaan konsep yang lebih tinggi menggunakan strategi STAD dapat diartikan bahwa strategi ini mampu memfasilitasi siswa yang memiliki keragaman gaya belajar. (Goethals et al., 2004) mengemukakan bahwa ada 4 cara siswa dalam berpikir atau mengolah informasi, yaitu; (1) mastery style; yaitu siswa menyerap informasi kongrit, memproses informasi secara berurutan, dan mempertimbangkan makna belajar dalam terminologi kejelasan dan kepraktisan, (2) understanding style; yaitu siswa fokus dalam ide dan abstraksi, belajar melalui proses bertanya, memberikan alasan, menguji, dan evaluasi belajar melalui standar-standar logika dan penggunaan fakta, (3) self-expressive style; yaitu siswa melihat sepintas, menggunakan perasaan (feeling) dan emosi untuk membangun ide-ide dan produk baru, dan mengevaluasi proses belajar menurut keaslian, keindahan, kepastian mengejutkan, dan (4) interpersonal style; yaitu siswa fokus dalam informasi nyata, lebih menyukai belajar secara sosial, dan menaksir belajar dalam terminologi apakah bermanfaat bagi siswa lainnya.

Keunggulan yang terjadi pada strategi STAD dibandingkan strategi konvensional adalah siswa saling bekerjasama untuk mencapai ketuntasan belajar bersama, siswa yang berkemampuan tinggi berperan sebagai tutor sebaya dalam kelompok yang heterogen (Arends, 2012). Dalam mewujudkan keberhasilan tujuan kelompok dalam pembelajaran kooperatif, (Goethals et al., 2004; Johnson \& Johnson, 2017) merekomendasikan praktik anggota kelompok sebagai berikut; 1) menjadi tahu dan saling percaya, 2) berkomunikasi secara akurat dan jelas, 3) saling menerima dan mendukung antara satu dan lainnya, dan 4) pemecahan masalah secara konstruktivis. Oleh sebab itu, dengan merefleksi proses selama aktivitas pembelajaran, siswa diberikan peluang untuk mencari dan memahami domain kognitif dalam keefektifan belajar untuk belajar (learning to learn), Hacker dalam (Branch \& Oberg, 2004). Berdasarkan uraian Johnson \& Johnson, Goethals, dan Hacker tersebut, terdapat relevansi strategi pembelajaran kooperatif STAD dan keterampilan metakognisi yaitu keterampilan metakognisi merupakan bagian dari keterampilan belajar untuk belajar (teaching to learn) yang dapat dipindahkan kedalam situasi belajar yang baru. Mengerti dan memahami pembelajaran merupakan suatu kekuatan pengalaman belajar bagi siswa dan guru.

Tampilan elaborasi konsep pada strategi STAD juga didukung (Ibrahim, 2000) mengemukakan bahwa pembelajaran dengan strategi kooperatif dikembangkan untuk mencapai 3 tujuan, yaitu; 1) untuk meningkatkan hasil belajar akademik, 2) mengembangkan penerimaan terhadap keberagaman atau perbedaan individual, dan 3) mengembangkan keterampilan sosial. Beberapa penelitian yang telah dilakukan umumnya juga berkesimpulan bahwa pembelajaran dengan strategi kooperatif meningkatkan hasil belajar kognitif siswa (Adnyana, 2004; Lord, 2001; Purwanti, 2003).

Menurut (Bennett, Rolheiser-Bennett, \& Stevahn, 1991) bahwa pembelajaran kooperatif merupakan sebuah strategi pembelajaran yang menekankan pada pengaturan bagaimana siswa-siswa bekerja sama dalam kelompok dengan tujuan pemecahan masalah bersama dan pengembangan interaksi sosial selain penguasaan bahan pembelajaran. Novak (Brown, 2003), agar siswa berhasil dalam belajar, siswa harus menguasai secara aktif apa yang telah diketahui, menemukan hubungan antar konsep, dan merekonstruksi kembali konsep dengan istilah dan pemahaman baru. Merekonstruksi konsep ketika berada dalam kelompok kecil dapat sangat memperkuat proses belajar. Kerjasama antar sesama siswa dalam kelompok memungkinkan siswa mempengaruhi dan saling belajar satu sama lainnya. Dalam kelompok, siswa dapat menunjukkan apa yang mereka ketahui tentang suatu objek ketika mendengar, mengamati, dan mempelajari dari siswa lain berdasarkan modifikasi hasil pemahaman mereka sendiri (Brown, 2003).

Thomson (Slavin, 1995) mengemukakan bahwa pembelajaran kooperatif mempunyai manfaat antara lain; memperdalam pemahaman, meningkatkan motivasi, meningkatkan hasil belajar, dan memperkaya referensi. (Oates, 2002) mengemukakan paling tidak ada tujuh keuntungan praktis proses pembelajaran, yaitu: 1) mendorong hubungan siswa, 2) mendorong kerjasama antar siswa, 3) mendorong siswa belajar aktif, 4) 
memberikan umpan balik yang cepat, 5) memberikan penegasan waktu tugas, 6) berhubungan dengan banyak dugaan, dan 7) tanggap terhadap perbedaan bakat dan cara belajar. (Lord, 2001) mengemukakan bahwa pembelajaran kooperatif dapat meningkatkan pemahaman siswa terhadap materi-materi biologi. Pembelajaran kooperatif menjadikan siswa lebih banyak bertanya, berbicara, dan menjawab pertanyaan sehingga pemahaman mereka akan materi pelajaran menjadi lebih baik.

Pembelajaran kooperatif STAD adalah pembelajaran yang secara sadar dan sistematis mengembangkan interaksi yang saling mencerdaskan, saling menyayangi, dan saling tenggang rasa antara sesama siswa, serta latihan hidup dalam masyarakat nyata. (Susilo, 2006) berpendapat bahwa pembelajaran kooperatif mengacu pada pandangan konstruktivis, yaitu siswa memperoleh pengetahuan sebagai akibat dari proses konstruksi yang terus-menerus diterima. Pengalaman-pengalaman diatur, disusun, dan ditata kembali dengan mengaitkan struktur kognitif yang dimiliki siswa, sedikit demi sedikit dimodifikasi dan dikembangkan. Dengan demikian, pengetahuan akan diciptakan dalam pikiran siswa sebagai hasil dari interaksi panca indera dengan lingkungannya.

\section{SIMPULAN DAN SARAN}

\section{Simpulan}

Strategi pembelajaran berpengaruh signifikan terhadap penguasaan konsep biologi. Strategi kooperatif STAD lebih efektif meningkatkan penguasaan konsep biologi siswa dibandingkan strategi konvensional.

\section{Saran}

Berdasarkan hasil penelitian dan pembahasan, peneliti menyarankan pada guru biologi untuk menerapkan strategi pembelajaran kooperatif STAD yang telah terbukti mampu meningkatkan penguasaan konsep biologi yang lebih baik dibandingkan strategi konvensional.

\section{DAFTAR RUJUKAN}

Adnyana, B. I. P. (2004). Pengembangan Model Pembelajaran Kooperatif Bermodul yang Berwawasan Sain Teknologi dan Masyarakat (STM) dan Pengaruh Implementasinya terhadap Hasil Belajar Biologi Siswa SMA di Singaraja. Universitas Negeri Malang.

Arends, R. I. (2008). Learning to Teach: Belajar untuk mengajar. Yogyakarta: Pustaka Pelajar.

Arends, R. I. (2012). Learning to Teach Ninth Edition. New York: Mc Graw Hill Book Co.

Arni, A., Jahidin, J., \& Suriana, S. (2019). Pengaruh Strategi Belajar M3k (Membaca, Mengidentifikasi Dan Menguji Konsep)-Metakognisi dalam Meningkatkan Pemahaman Konsep dan Mereduksi Miskonsepsi Materi Sistem Ekskresi Siswa. Jurnal Biofiskim: Pendidikan Dan Pembelajaran Ipa, 1(1).

Bennett, B. B., Rolheiser-Bennett, N. C., \& Stevahn, L. (1991). Cooperative learning: Where heart meets mind: An interactive resource book. Educational Connections Toronto.

Branch, J., \& Oberg, D. (2004). Focus on inquiry: A teacher's guide to implementing inquiry-based learning. Canada: Alberta Education, Alberta.

Brown, D. S. (2003). High school biology: A group approach to concept mapping. The American Biology Teacher, 65(3), 192197.

Degeng, I. N. S. (1989). Ilmu pengajaran dan Taksonomi Pembelajaran. Jakarta: Depdikbud, Dirjen Pendidikan Tinggi Proyek Pengembangan LPTK.

Goethals, M. S., Howard, R. A., \& Sanders, M. M. (2004). Student teaching: a process approach to reflective practice: a guide for preservice and inservice teachers. Pearson/Merrill/Prentice Hall.

Good, T. L., \& Brophy, J. E. (2000). Looking in classrooms. New York: Longman Publishing.

Ibrahim, M. (2000). Pembelajaran kooperatif. Surabaya: University Press.

Johnson, D. W., \& Johnson, R. . (2017). Cooperative Learning.

Lie, A. (2002). Cooperative learning. Jakarta: Grasindo.

Lord, T. R. (2001). 101 reasons for using cooperative learning in biology teaching. The American Biology Teacher, 63(1), 3039.

Newmann, F. M., \& Thompson, J. A. (1987). Effects of Cooperative Learning on Achievement in Secondary Schools: A Summary of Research.

Norman, D. G. (2005). Using STAD in an EFL elementary school classroom in South Korea: Effects on student achievement, motivation, and attitudes toward cooperative learning. Asian EFL Journal, 35(3), 419-454.

Oates, K. K. (2002). Inquiry science: Case study in antibiotic prospecting. The American Biology Teacher, $184-187$. 
Osborn, A. F. (1963). Applied imagination (3rd ed., Vol. 7). New York: Charles Scribner's Sons.

Piaget, J. (1975). The construction of reality in the child. New York: Penguin Book.

Purwanti, W. C. (2003). Meningkatkan Hasil Belajar MIPA. Seminar Pendidikan Matematika Dan IPA. Malang: UM Press.

Schulz-Hardt, S., Jochims, M., \& Frey, D. (2002). Productive conflict in group decision making: Genuine and contrived dissent as strategies to counteract biased information seeking. Organizational Behavior and Human Decision Processes, 88(2), 563-586.

Slavin, R. E. (1995). Cooperative learning second edition. Massachusett: Allyn and Bacon Publisher.

Slavin, R. E. (2005). Cooperative Learning Theory, Research and Practice. Bandung: Nusa Media.

Slavin, R. E. (2006). Educational Psychologhy Theory and Practice (8th ed.). United States of America: Pearson Education.

Soedjono, B. (2007). Pengaruh Pembelajaran Tugas Autentik Klasikal dan Non Klasikal dalam Strategi Kooperatif STAD dan GI Terhadap Pencapaian Kompetensi Biologi Peserta Didik kelas XI SMAN di Kota Malang yang Berkemampuan Akademik Berbeda. Universitas Negeri Malang.

Susilo, H. (2006). Apa dan Mengapa Lesson Study Perlu Dilakukan untuk Meningkatkan Profesionalisme Guru dan Dosen MIPA. Makalah. Disajikan Dalam Seminar Peningkatan Profesionalisme Guru Dan Dosen MIPA Melalui Lesson Study, Di Singaraja, 25.

Toseland, R. W., Jones, L. V., \& Gellis, Z. D. (2004). Group dynamics. The Guilford Press.

Vygotsky, L. S. (1994). The problem of the environment. The Vygotsky Reader, 338-354.

Widodo, S. W. F. (2017). Pengaruh Strategi Pembelajaran Biologi Cooperative Script dan Reading-Concept MapCooperative Script (Remap-CS) terhadap Keterampilan Metakognitif, Motivasi Belajar, dan Retensi Siswa Kelas X SMA di Kota Malang. Universitas Negeri Malang. 